\title{
The State of Tour Operators in Slovakia before the COVID-19 Pandemic ${ }^{1}$
}

\author{
Kristína POMPUROVÁ - L'ubica ŠEBOVÁ - Ján ŠEBO - \\ Marta VALIHOROVÁ - Alena KAŠĆÁKOVÁ*
}

\begin{abstract}
The COVID-19 pandemic has significantly paralyzed tour operators' activities around the world. The purpose of this paper is to analyze the state of tour operators using the example of Slovakia and to point out its specifics that may affect its recovery. This paper identifies active tour operators, recognizing them in terms of selected criteria and uses cluster analysis to reveal consistent groups of enterprises. It is based mostly on content analysis of relevant websites. The results show there is a moderate level of concentration that characterizes Slovak tour operators with four large enterprises generating more than a third of all revenues. A typical tour operator in Slovakia is an outbound micro-enterprise with $3 S$ mass product which intervenes in the activities of travel agency. The authors estimate that due to the Covid-19 pandemic measures, many tour operators will disappear, transform into pure travel agency or leave mass holidays product.
\end{abstract}

Keywords: tour operators, tour operator industry, cluster analysis, Slovakia JEL Classification: M11, M21, Z31, Z32

DOI: https://doi.org/10.31577/ekoncas.2021.09.05

\section{Introduction}

Tourism is one of the most dynamic sectors of the economy providing considerable opportunities for socio-economic development. According to the World Tourism Organization, the European tourism economy contributes between

\footnotetext{
* Kristína POMPUROVÁ, corresponding author - L’ubica ŠEBOVÁ - Ján ŠEBO - Marta VALIHOROVÁ - Alena KAŠČÁKOVÁ, Matej Bel University in Banská Bystrica, Faculty of Economics, Department of Tourism, Tajovského 10, 97590 Banská Bystrica, Slovakia; e-mail: kristina.pompurova@umb.sk; lubica.sebova@umb.sk; jan.sebo@umb.sk; marta.valihorova2@umb.sk; alena.kascakova@umb.sk

${ }^{1}$ This research was funded by the Scientific Grant Agency of the Ministry of Education, Science, Research and Sport of Slovak Republic VEGA, grant number 1/0368/20 Sharing economy as an opportunity for sustainable and competitive development of tourist destinations in Slovakia.
} 
5 and $11 \%$ of the GDP in the European Union and provides between 8 to 24 million jobs, depending on the definition of the sector (Linderová and Janeček, 2017). In 2018, the total tourism industry contribution to the world economy was $10.4 \%$ of global GDP, $6.5 \%$ of total global exports, $27.2 \%$ of total services exports and $10 \%$ of total world employment (Erceg, Sekuloska and Kelić, 2020).

At the beginning of 2020, when the restrictions connected with the COVID-19 pandemic dramatically devastated the tourism industry, tourist operators had been enjoying one of the largest and fastest growing segments of the tourism and hospitality industry (Dhiman and Kumar, 2019). Although tour operators are key role players in facilitating tourist demand and in tourist destination development, they have rarely been the focus of research (Holland and Leslie, 2018). Unlike accommodation facilities, which are often the subject of various analysis, our knowledge and understanding of tour operators is not yet commensurate with the economic and social significance of the phenomenon (Dhiman and Kumar, 2019). The reasons are undoubtedly the missing or difficult to access data with numbers, characteristics and performance of active tour operators in each market.

Our intention is to fill this gap, analyze the state of tour operators and point out its specifics that may affect its recovery. The paper is structured as follows: First, it presents various approaches of scientific literature about tour operator analysis and points out that existing analysis are not specific and therefore inadequate. Next, the paper introduces material and methods of research and then focuses on the research results. It identifies active tour operators in a given market, recognizes them in terms of selected criteria and thanks to cluster analysis reveals multidimensional consistent groups of enterprises. The paper deal with the following research questions:

RQ1: Are Slovak tour operators' industry too concentrated?

RQ2: What packages of travel services are affected with Slovak tour operators?

RQ3: What defines a typical tour operator in Slovakia?

RQ4: What parameters make possible the defining of relatively homogeneous groups of tour operators in Slovakia?

In the discussion, the paper compares obtained outputs with earlier studies and in conclusion, it compares the results and outlines the need for a more significant departure from mass product.

\section{Tour Operators in the Spotlight of Scientific Literature}

In the available scientific literature, various themes related with tour operators are discussed. Four key topics play an important role, namely (1) legislation, (2) impact of tour operators on other entities, specific influence on accommodation 
facilities, the effects of tourist opinions and on image of selected destinations, as well as influence of tour operators on sustainable territorial development, (3) marketing mix of tour operators, concrete product, quality of services provided, position in the distribution system, marketing tools and role of innovation within corporate tour operators and (4) tour operators market analysis.

In prestigious literature, the analysis of the tour operators has been particularly emphasized. While some authors (Marin-Pantelescu and Maniu, 2014; Derco, 2018) rely on generally available statistics on tour operators' performance (e.g., sales, number of clients, average length of stay, preferred destination countries, etc.), they do not further evaluate, others (Pachingerová, 2001; Assaf, Barros and Dieke, 2011; Hedija, 2017; 2019; Hedija and Kuncová, 2018; Onuferová and Čabinová, 2018; Šolcová and Petrikovič, 2019) are devoted to a more or less in-depth analysis of financial indicators, i.e., performance of tour operators in specific markets. A comparison of tour operators in different countries is, with one exception (Assaf, Barros and Dieke, 2011), missing, due to hard-to-reach comparable data.

Marin-Pantelescu and Maniu (2014) analyzed tour operators in Romania with the number of clients, preferred destinations of Romanian tourists, etc. Similarly, Derco (2018) presented the performance of tour operators in Slovakia (income, number of clients, average length of stay, etc.). He added the median values of selected financial indicators, obtained from the database of financial statements of enterprises without further interpretation.

Pachingerová (2001) evaluated medians/quartiles of financial indicators of tour operators in Slovakia. Assaf, Barros and Dieke (2011) based on data envelopment analysis (DEA) questioned the sources of efficiency improvements with Spanish and Portuguese tour operators focusing on the firm size, group ownership, mergers and acquisitions. The authors claim that group membership and mergers and acquisitions positively affect tour operator efficiency. Hedija (2017) and Hedija and Kuncová (2018) assess the financial health of tour operators in the Czech Republic using and comparing the results of different methods. The multiple criteria decision making methods (TOPSIS and WSA) based on selected financial ratios and bankruptcy models were applied. The findings show that approximately 30 percent of existing tour operators and tour operators were threatened by bankruptcy in 2014 and it is expected that the market will evolve towards a reduction of their number. Hedija (2019) also tests the reliability of selected bankruptcy models as a predictor of financial distress of the sample of selected tour operators and tour operators for which financial data were available. Onuferová and Čabinová (2018) created and applied the Modified 3D Creditworthy Model of performance reflecting sectoral characteristics and financial 
specificities of the selected sample (57) of Slovak tour operators which employ more than 5 employees. As a results of model application over the years 2013 2017, the financial health dimension of selected Slovak tour operators had a performance field of "standard" and the prediction analysis was in the "monitor" performance field. In the field of Return on Equity, however the performances were considering to have the worst result in terms of wealth creation. Šolcová and Petrikovič (2019) focused on the evaluation of a specific German tour operator in the Slovak market. During the years 2011 to 2017, they analyzed the number of its clients, turnover, profit and the number of agents that mediate the product of a given tour operator in individual regions of Slovakia. They were based on secondary sources and their own research.

The available literature highlighting tour operators, approached the issue nonspecifically, without taking into account the specificities of tour operators as tourism businesses. It is this research gap that we desire to complete.

\section{Materials and Methods}

The aim of the paper is to multidimensionally analyze the current state of the tour operators before COVID-19 and point out its specifics that may affect its recovery from the crisis in the example of Slovakia. The reason for choosing this country is knowledge of the TOs market.

First, we identify all active tour operators on the market, second, we recognize them in terms of the criteria by which they differ - i.e. legal form (Orieška, 2011), size (Orieška, 2011; Pompurová, 2011; Holland and Leslie, 2018), location (Orieška, 2011; Pompurová, 2011; Gajdošík, Gajdošíková and Marčeková, 2017), product (Buhalis and Laws, 2001; Gúčik et al., 2006; Holloway, 2009; Orieška, 2011; Pompurová, 2011; Holland and Leslie, 2018), affiliation to selected organizations (Orieška, 2011), revenue (Orieška, 2011) - and finally, since the categorization of tour operators according to individual criteria is only one-dimensional, we used a Two-Step Cluster Analysis as an exploratory tool designed to reveal natural groupings from the multidimensional aspect within a data set that would otherwise not be apparent. The algorithm employed by this procedure has several desirable features that differentiate it from traditional clustering techniques the ability to create clusters based on both categorical and continuous variables, automatic selection of the number of clusters and the ability to analyze large data files efficiently. Two-Step Cluster Analysis identifies groupings by running preclustering first and then by running hierarchical methods.

In order to answer the second research question and test whether there is a statistically significant relationship between the planned revenues from packages 
of travel services and the observed characteristics of active tour operators, we used correlation analysis. The choice of a particular correlation coefficient depended on the type of variable examined; the non-parametric Spearman coefficient was most often used, which value $r=1$ means a perfect positive correlation and the value $r=-1$ means a perfect negative correlation.

Whereas available financial statistics used by previous studies (Pachingerová, 2001; Hedija, 2017, 2019; Derco, 2018; Hedija and Kuncová, 2018) (1) do not include information about individuals (2) are not able to identify whether the firms in question are active tour operators - whether and what part of their revenues come from the sale of packages of travel services (and what part is related to the sale of air tickets, other individual services or products), nor to (3) identify the characteristics more specifically illustrating tour operator enterprises, we have relied primarily on the list of tour operators published by The Slovak Trade Inspection Authority.

Based on Act No. 170/2018 Law on packages of travel services and linked travel arrangements (...), the Slovak Trade Inspection Authority, as the supervisory body of this Act, maintains and publishes on its website an up-to-date list of tour operators that create packages of travel services and intermediate linked travel arrangements and has protection in case of insolvency. As of 31 December 2019, 259 tour operators were registered on the list, of which $10.4 \%$ (27) of those planned in the given year or were forced (prohibition granted) to perform only intermediary activities. We therefore excluded them from further research and focused on the remaining 232 entities that can be identified as active tour operators.

We used the content analysis of relevant websites (websites and accounts on social networks of individual 232 tour operators, database of economic results of Slovak companies FinStat, website of Slovak Association of Tour operators and Travel Agents) and electronic communication with representatives of selected tour operators. Unlike previous non-specific analysis, we also focused on information typical for tour operators (tour operators' product, their reference to the Slovak Association of Tour operators and Travel Agents, and to the International Air Transport Association IATA, revenues of the tour operators from their "own product", it means from the sale of organized packages of travel services).

Collecting data was provided during the months of January to May 2020. From the data about the sum providing protection against insolvency available on the web site of The Slovak Trade Inspection Authority, we derived the amount of planned revenues of the tour operator from the sale of packages of travel services and linked travel arrangements for $2019 .^{2}$

\footnotetext{
${ }^{2}$ Planned revenues $=$ sum providing protection against insolvency $/ 0.30$.
} 
According to Act No. 170/2018 Coll. on packages of travel services and linked travel arrangements (...), the tour operator is obliged to agree with the provider of insolvency protection (insurance company, bank) on the amount of insolvency protection in the amount of at least $30 \%$ of the annual planned revenues from the sale of packages of travel services and linked travel arrangements when concluding a contract providing bankruptcy protection. As the uncertainty of the definition of linked travel arrangements discourages traders from selling them (Jurčová, 2020), in practice tour operators do not sell linked travel arrangements on the Slovak market. Ergo, the amount of insolvency protection is agreed from the amount of planned revenues from the sale of packages. The insurance companies thoroughly check the financial results and plans of the tour operator several times for the next season. The Slovak Trade Inspection also checks the amount providing protection in the event of bankruptcy after comprehensive analysis on a quarterly basis. We consider these figures sufficiently reliable to calculate planned sales of packages. On the other hand, we are aware that the data reflects the situation of the ceteris paribus i.e., only the plan and unexpected situations, such as terrorist attacks at the destination in which the tour operator specializes or a ban on the use of a certain type of aircraft (e.g., Boeing 737 MAX in 2019) can more or less significantly affect a plan. However, we believe that the information on planned revenues is sufficient to depict the tour operators' industry in Slovakia. The disadvantage of the given procedure is the impossibility to monitor the data on planned revenues through a longer period of time, as Act No. 170/2018 Coll. and also the obligation to keep a database of tour operators, came into force only on January 1, 2019.

We processed the obtained data in the statistical software SPSS, through which we evaluated them at a significance level of 0.05 ordinarily used in this type of research.

\section{Results}

According to data from the database of economic results of Slovak companies FinStat, in the last five years for which complete data are available (2014 2018), there were 327 tour operators on the Slovak market which were legal persons. They achieved average annual revenues of 567.7 thousand euros per year, with the highest revenues reaching in 2017. In the period under review, they employed an only average of 1.4 employees, which is an extremely low number. Value added per employee was 70.8 thousand euros on average. As well as Hedija (2017) and Hedija and Kuncová (2018), we used Altman's Z-Score model to assess the financial health of tour operators. While $51.6 \%$ of companies 
was in the safe zone (the largest share $-52.8 \%$ in 2014), $21.0 \%$ were in the grey area and $27.4 \%$ in the distress zone (the most was in $2018-29.3 \%$ ). As in the case of the Czech market (Hedija, 2017), the number of tour operators is relative high and this number converted per capita is among the highest in the European Union. Similarly, the findings show that not all enterprises are in good financial health and it is expected that the market of tour operators will evolve towards a reduction of the number of market players. This may be exacerbated by the crisis caused by the corona pandemic and related restrictions.

Although the financial statistics can show remarkable information, it has several serious shortcomings and misleading results. We have also relied primarily on the list of tour operators published by The Slovak Trade Inspection Authority, which allowed us to analyze the current state of tour operators specifically.

As of 31 December 2019, 232 entities were recorded in the list maintained by the Slovak Trade Inspection Authority, which, according to Act No. 170/2018 Coll. a contract signed for 2019 providing protection against insolvency. We can therefore call these companies active tour operators that actually organize packages of travel services. Their number is significantly lower than the number of tour operators listed in the financial statistics. As the Slovak Trade Inspection Authority updates the information in the list of tour operators on an ongoing basis, this is data valid as of the given date of publication. The information in the list is supplemented on the basis of any change obtained ex officio or on the basis of a notification from the Ministry of the Interior of the Slovak Republic, the bankruptcy protection provider and the tour operator. At the same time, tour operators are obliged to report changes to the registered data and to deliver a current and valid contract providing protection against insolvency.

\subsection{Tour Operators' Characteristics}

The subchapter characterizes tour operators in terms of the criteria by which individual enterprises differ i.e., legal form, size, location, product, affiliation to selected organizations and revenues, while it tries to answer three research questions.

The majority of tour operators in the Slovak market operate as a limited liability company (Table 1), which is in line with other economic industries.

In terms of size, tour operators in Slovakia can be described as micro respectively, small businesses, which also does not deviate from the general framework of Slovak enterprises, but is different from the Western European market of tour operators. According to the Tourism Satellite Account of the Slovak Republic, together with travel agencies, they employ only about $2 \%$ of the total number of employees in the characteristic tourism sectors. More than half of tour operators 
employ no more than one employee. Almost $86 \%$ of tour operators have less than ten employees, more than 95\% employ less than 25 individuals and more than $97 \%$ have up to 50 employees. Their disadvantages include a lower level of company management, lower efficiency with modern information technologies, more complex entry of the company into the tourism market, as well as limited access to capital.

T a ble 1

\section{Tour Operators' Industry Characteristics}

\begin{tabular}{|c|c|c|c|}
\hline \multicolumn{4}{|c|}{ Tour operators according to legal form } \\
\hline Legal form & Number of tour operators & Share in \% & Cumulative share in $\%$ \\
\hline $\begin{array}{l}\text { Trade licence company } \\
\text { Limited liability company } \\
\text { As joint stock company } \\
\text { Organizational unit } \\
\text { of the company }\end{array}$ & $\begin{array}{r}37 \\
185 \\
8 \\
\\
2\end{array}$ & $\begin{array}{r}16.0 \\
79.7 \\
3.4 \\
\\
0.9 \\
\end{array}$ & $\begin{array}{r}16.0 \\
95.7 \\
99.1 \\
\\
100.0 \\
\end{array}$ \\
\hline \multicolumn{4}{|c|}{ Tour operators according to the number of employees } \\
\hline Number of employees & Number of tour operators & Share in \% & Cumulative share in \% \\
\hline $\begin{array}{l}0-1 \\
2 \\
3-4 \\
5-9 \\
10-24 \\
25-49 \\
50-99 \\
100-149 \\
250-499 \\
\end{array}$ & $\begin{array}{r}118 \\
25 \\
27 \\
29 \\
22 \\
5 \\
3 \\
2 \\
1 \\
\end{array}$ & $\begin{array}{r}50.9 \\
10.8 \\
11.6 \\
12.5 \\
9.5 \\
2.2 \\
1.3 \\
0.9 \\
0.4 \\
\end{array}$ & $\begin{array}{r}50.9 \\
61.6 \\
73.3 \\
85.8 \\
95.3 \\
97.4 \\
98.7 \\
99.6 \\
100.0 \\
\end{array}$ \\
\hline \multicolumn{4}{|c|}{ Tour operators according to the number of branches } \\
\hline Number of branches & Number of tour operators & Share in \% & Cumulative share in $\%$ \\
\hline $\begin{array}{l}0 \\
1 \\
2 \\
3 \\
4 \\
7 \\
10 \\
11 \\
13 \\
15 \\
44 \\
\end{array}$ & $\begin{array}{r}17 \\
189 \\
8 \\
6 \\
1 \\
2 \\
1 \\
3 \\
3 \\
1 \\
1 \\
\end{array}$ & $\begin{array}{r}7.3 \\
81.5 \\
3.4 \\
2.6 \\
0.4 \\
0.9 \\
0.4 \\
1.3 \\
1.3 \\
0.4 \\
0.4 \\
\end{array}$ & $\begin{array}{r}7.3 \\
88.8 \\
92.2 \\
94.8 \\
95.3 \\
96.1 \\
96.6 \\
97.8 \\
99.1 \\
99.6 \\
100.0 \\
\end{array}$ \\
\hline \multicolumn{4}{|c|}{ District of the localized seat of the tour operators } \\
\hline Region & Number of tour operators & Share in \% & Part of Slovakia \\
\hline $\begin{array}{l}\text { Bratislava } \\
\text { Trenčín } \\
\text { Trnava } \\
\text { Nitra }\end{array}$ & $\begin{array}{l}93 \\
11 \\
27 \\
19\end{array}$ & $\begin{array}{r}40.1 \\
4.7 \\
11.6 \\
8.2\end{array}$ & $\begin{array}{l}\text { Western Slovakia } \\
(150 \text { subjects, } 64.6 \%)\end{array}$ \\
\hline $\begin{array}{l}\text { Banská Bystrica } \\
\text { Žilina }\end{array}$ & $\begin{array}{l}20 \\
25\end{array}$ & $\begin{array}{r}8.6 \\
10.8 \\
\end{array}$ & $\begin{array}{l}\text { Central Slovakia } \\
(45 \text { subjects, } 19.4 \%)\end{array}$ \\
\hline $\begin{array}{l}\text { Košice } \\
\text { Prešov }\end{array}$ & $\begin{array}{l}22 \\
15 \\
\end{array}$ & $\begin{array}{l}9.5 \\
6.5 \\
\end{array}$ & $\begin{array}{l}\text { Eastern Slovakia } \\
(37 \text { subjects, } 16.0 \%)\end{array}$ \\
\hline
\end{tabular}




\begin{tabular}{|c|c|c|c|}
\hline \multicolumn{4}{|c|}{ Tour operators according to the size of the city they are seated in } \\
\hline Size of the municipality & Number of tour operators & Share in $\%$ & Cumulative share in \% \\
\hline $\begin{array}{l}0-199 \\
200-499 \\
500-999 \\
1000-1999 \\
2000-4999 \\
5000-9999 \\
10000-19999 \\
20000-49999 \\
50000-99999 \\
100000+\end{array}$ & $\begin{array}{r}0 \\
1 \\
5 \\
6 \\
5 \\
9 \\
10 \\
39 \\
50 \\
107\end{array}$ & $\begin{array}{r}0.0 \\
0.4 \\
2.2 \\
2.6 \\
2.2 \\
3.9 \\
4.3 \\
16.8 \\
21.6 \\
46.1\end{array}$ & $\begin{array}{r}0.0 \\
0.4 \\
2.6 \\
5.2 \\
7.3 \\
11.2 \\
15.5 \\
32.3 \\
53.9 \\
100.0\end{array}$ \\
\hline \multicolumn{4}{|c|}{ Tour operators according to the size of the city they are seated in } \\
\hline Size of the municipality & Number of tour operators & Share in $\%$ & Cumulative share in $\%$ \\
\hline $\begin{array}{l}0-199 \\
200-499 \\
500-999 \\
1000-1999 \\
2000-4999 \\
5000-9999 \\
10000-19999 \\
20000-49999 \\
50000-99999 \\
100000+ \\
\end{array}$ & $\begin{array}{r}0 \\
1 \\
5 \\
6 \\
5 \\
9 \\
10 \\
39 \\
50 \\
107 \\
\end{array}$ & $\begin{array}{r}0.0 \\
0.4 \\
2.2 \\
2.6 \\
2.2 \\
3.9 \\
4.3 \\
16.8 \\
21.6 \\
46.1 \\
\end{array}$ & $\begin{array}{r}0.0 \\
0.4 \\
2.6 \\
5.2 \\
7.3 \\
11.2 \\
15.5 \\
32.3 \\
53.9 \\
100.0 \\
\end{array}$ \\
\hline \multicolumn{4}{|c|}{ Tour operators according to the type of tourism they focus on } \\
\hline Type of tourism & Number of tour operators & Share in \% & Cumulative share in \% \\
\hline $\begin{array}{l}\text { the domestic operator } \\
\text { incoming operator } \\
\text { outgoing operator }\end{array}$ & $\begin{array}{r}19 \\
8 \\
205\end{array}$ & $\begin{array}{r}8.2 \\
3.4 \\
88.4 \\
\end{array}$ & $\begin{array}{r}8.2 \\
11.6 \\
100.0\end{array}$ \\
\hline \multicolumn{4}{|c|}{ Tour operators according to the product specialization } \\
\hline Product specialization & Number of tour operators & Share in $\%$ & Cumulative share in \% \\
\hline $\begin{array}{l}\text { general tour operator } \\
\text { specialized tour operator }\end{array}$ & $\begin{array}{l}129 \\
103 \\
\end{array}$ & $\begin{array}{l}55.6 \\
44.4 \\
\end{array}$ & $\begin{array}{r}55.6 \\
100.0\end{array}$ \\
\hline \multicolumn{4}{|c|}{ Tour operators according to the number of destination in the product portfolio } \\
\hline Number of destination & Number of tour operators & Share in \% & Cumulative share in \% \\
\hline $\begin{array}{l}1 \\
2-3 \\
4 \text { and more }\end{array}$ & $\begin{array}{r}39 \\
15 \\
178\end{array}$ & $\begin{array}{r}16.8 \\
6.5 \\
76.7\end{array}$ & $\begin{array}{r}16.8 \\
23.3 \\
100.0\end{array}$ \\
\hline \multicolumn{4}{|c|}{ Tour operators according to planned revenues in year 2019} \\
\hline Revenues in EUR & Number of tour operators & Share in $\%$ & Cumulative share in $\%$ \\
\hline $\begin{array}{l}\text { Up to } 10,000 \\
\text { Up to } 50,000 \\
\text { Up to } 100,000 \\
\text { Up to } 200,000 \\
\text { Up to } 500,000 \\
\text { Up to } 1,000,000 \\
\text { Up to } 2,000,000 \\
\text { Up to } 5,000,000 \\
\text { Up to } 10,000,000 \\
\text { More than } 10,000,000\end{array}$ & $\begin{array}{r}6 \\
52 \\
43 \\
31 \\
44 \\
18 \\
11 \\
12 \\
8 \\
7 \\
\end{array}$ & $\begin{array}{r}2.6 \\
22.4 \\
18.5 \\
13.4 \\
19.0 \\
7.8 \\
4.7 \\
5.2 \\
3.4 \\
3.0 \\
\end{array}$ & $\begin{array}{r}2.6 \\
25.0 \\
43.5 \\
56.9 \\
75.9 \\
83.6 \\
88.4 \\
93.5 \\
97.0 \\
100.0 \\
\end{array}$ \\
\hline Total & 232 & 100.0 & - \\
\hline
\end{tabular}

Source: Authors calculation. 
More than three quarters $(81.5 \%)$ of Slovak tour operators have only one physical location, while $7.3 \%$ have none. This testifies to the growing confidence of clients in the online sale of packages, despite their special characteristics compared to a common consumer product, but also to the considerable use of commission sales. More than 10 branches have only a negligible percentage $(3.4 \%)$ of tour operators.

Tour operators in the Slovak market are naturally concentrated in regions with a higher purchasing power of the population (western Slovakia). However, there are differences in the location of tour operator headquarters not only between East $(16.0 \%)$ and West (64.6\%), but also within the West Slovakian region (Table 1). The Bratislava Region has up to $40.1 \%$ of all tour operators (45 per 1000 $\mathrm{km}^{2}$ ), while there is only $4.7 \%$ located in the Trenčín Region $\left(2\right.$ per $\left.1000 \mathrm{~km}^{2}\right)$.

Only $15.5 \%$ of tour operators are located in municipalities with a population of up to 20,000. The largest number of entities are located in the only two cities with a population over 100,000 inhabitants, Bratislava and Košice. The majority (67.2\%) are based in the regional city (eight in total). While in the capital (Bratislava) there are 21 tour operators per 100,000 inhabitants; in Košice, the second largest city located in the East, has only eight.

The tour operators have specialized role: domestic operators, inbound operators and outbound operators (Holloway, 2009). The domestic operator organizes package holidays to a destination within the country in which the tourists reside, the inbound operators are handling foreign visitors for holidays and outbound operator deals with those tourists that want to spend their holidays outside their residence country.

We found that the vast majority $(88.4 \%)$ of active tour operators are primarily focused on outbound tourism (Table 1), which is not an ideal solution in connection with COVID-19 pandemic measures. However, it is necessary to note that in collecting and analyzing data, we abstracted from the fact that some tour operators may deal with several types of tourism at once and we took into account only the one that was in their prevailing product. At the same time, the market is slightly dominated $(55.6 \%)$ by companies that offer a heterogeneous mass product in numerous well known, mostly seaside destinations to diverse customers. This relates to the location of Slovakia in the middle of Europe, which assumes that the holiday plans of the inhabitants, to which tour operators try to adapt, are more homogeneous and oriented to the sea, and thus to the traditional 3S (sea, sand, sun) mass holidays product. Only $44.4 \%$ can be described as specialized tour operators. These are often presented as experts on a selected destination. Specialized tour operators also pay attention to special types of tourism (e.g. business tourism, religious tourism, spa tourism, sports tourism). Some entities 
try to use the identified hole in the market and focus the content of the tour on events, wine tours, packages related to train travel or packages generally aimed at sustainable tourism. Some specialized tour operators adapt their offer to the selected target group, while entities with an offer for children in the school environment have a dominant position here. As static packages are symptomatic for general (non-specialized) tour operators in Slovakia, it is also possible to name as specialized enterprises those tour operators which focus their offer on sightseeing tours.

Only a small part (37.9\%) of tour operators show confidence in the trade organization with its membership in the Slovak Association of Tour operators and Travel Agents, and only a negligible amount (7.3\%) is the so called IATA agent (i.e. intensively involved in air ticket sales).

Tour operators listed in the register of the Slovak Trade Inspection Authority planned revenues in 2019 from the sale of packages of travel services in the amount of 344.4 mil. euros. While on average there is 1.3 mil. EUR per tour operator, the median value of the given revenues is only at the level of 103,373 EUR. Thus, at least half of the given subjects can be described only as occasional tour operators.

Despite multinational tour operators not operating to a greater extent in Slovakia, the fact that up to $37.3 \%$ of all planned revenues fall on four $(1.7 \%)$ of companies, prove the considerable consolidation on the tour operator market. Concentration Ratio $\left(\mathrm{CR}_{4}=0,37\right)$ explaining the percentage of market share taken up by four largest firms according to the Federal Trade Commission in USA $\left(0,25 \leq \mathrm{CR}_{4}<0,50\right)$ indicates moderate concentration of the tour operator industry (Brezina, Oršulová and Pekár, 2009). Its increase may be an indication of a fall in competitive pressures and could lead to higher prices of packages of travel services for customers.

However, when we take into account the Herfindahl-Hirschman Index, calculated by squaring the market share of each firm competing in a market and then summing the resulting numbers, according to Brezina, Oršulová and Pekár (2009), we must state that supply in the sector is not concentrated (HHI <0,10). Anyhow, TOP 4 enterprises on the Slovak market have a significant market share. All of them are general outbound tour operators with at least eleven physical branches $(11-44)$ and at least 25 employees. They are all members of the Slovak Association of Tour operators and Travel Agents, based in the capital.

More than half of the tour operators on the list, whose planned revenues do not exceed 200 thousand euros (Table 1) is in a completely opposite position. We assume that these are companies that profit mainly from commission activities, while some of them focus on the sale of packages of travel services of foreign 
tour operators (especially Austrian and German tour operators). However, in the list registered by the Slovak Trade Inspection Authority we can also find such companies whose primary activity is significantly different from the creation and sale of packages of travel services. There are also individuals who achieve minimum sales, and or who simultaneously work as employees for other entities or are on maternity or parental leave.

We tested whether there is a correlation between the amount of planned revenues from the sale of packages of travel services and the examined features of tour operators. We confirmed it only in the case of the size of the municipality where the tour operator's seat is located ( $\mathrm{p}$-value $=0.000, \mathrm{rs}=0.232$ ), the number of employees ( $\mathrm{p}$-value $=0.000, \mathrm{rs}=0.446)$ and the number of branches (p-value $=0.000, r s=0.314)$. While the values of the Spearman coefficient indicate that there is only a very low positive relationship between the planned sales and the size of the tour operator's seat, between the planned revenues and the number of branches, and or the number of employees is slightly more dependent, i.e. the planned revenues with the number of branches and the number of employees of tour operators are slightly increasing. However, the tour operator market is currently significantly affected by the sale of products over the Internet.

\subsection{Clusters of Tour Operators}

In order to understand better the tour operator industry, we used cluster analysis to identify relatively homogeneous groups of tour operators in terms of data on their legal form, size (number of employees, number of branches), location, product, membership in researched associations and planned revenues from packages. Statistical software has proposed suitable segments of tour operators into which they tend to cluster naturally. As the clusters formed were not sufficiently stable, we gradually excluded several characteristics of the subjects from the criteria.

We identified four clusters, the structure of which expressed by the parameter so-called silhouettes of the degree of coherence and the separation is acceptable (Figure 1).

We state that in the analyzed period there were four groups of tour operators in Slovakia, which are relatively homogeneous in terms of the number of employees, planned revenues and membership in associations (Table 2).

Big players are the least numerous cluster. They are characterized by an extremely high level of integration into the trade union (100\%) as well as IATA $(50.0 \%)$, a significant number of employees compared to the average $(78.6 \%$ have at least 10 employees) and the highest average planned sales of packages of travel services (on average 7.7 million EUR). However, the high standard 
deviation indicates that the planned sales are differentiated in this group. While less than a third (32.1\%) planned revenues from the sale of own packages of travel services for a maximum of 200 thousand euros in $2019,7.1 \%$ planned to collect from 200 thousand euros to one million euros and the majority $(60.8 \%)$ considered more than a million revenues (while $35.7 \%$ of entities planned to sell their own packages of travel services for at least 5 million EUR).

Figure 1

\section{Cluster Creation}

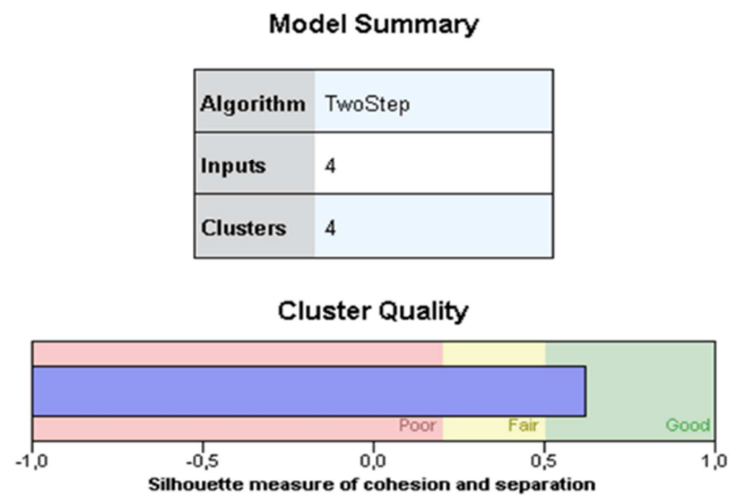

Source: SPSS output.

Table 2

\section{Cluster Distribution}

\begin{tabular}{|l|c|c|c|}
\hline Clusters & N & \% of Combined & \% of Total \\
\hline Big players & 28 & 12.1 & 12.1 \\
Successful solitaires & 56 & 24.1 & 24.1 \\
Small partners & 60 & 25.9 & 25.9 \\
Independent drawers & 88 & 37.9 & 37.9 \\
Combined & 232 & 100.0 & 100.0 \\
\hline
\end{tabular}

Source: SPSS output and own processing.

All of the TOP4 Slovak tour operators in terms of sales belong to the given group. The Big players have branches in Western Slovakia (85.7\%), in regional cities (82.1\%), in Bratislava and Košice (71.4\%). 64.3\% are based in the capital (Bratislava). Up to $96.4 \%$ are operated as a legal entity. All entities in the cluster offer more destination countries, the vast majority (96.4\%) offers their products in outbound tourism and up to $75.0 \%$ is without specialization. While half have only one physical location, $32.1 \%$ have more than five (the top 3 have 11,13 or 44 branches).

The cluster of Successful solitaires is characterized by independence. None of the tour operators is a member of the Slovak Association of Tour operators and 
Travel Agents and only 2 are members of IATA (Table 3). Nevertheless, in 2019 they planned to achieve solid revenues from the sale of their own packages of travel services (on average, 1.5 million EUR). However, as the standard deviation suggests, the distribution of these revenues is far from uniform. Almost half (46.3\%) planned sales of up to 200 thousand EUR, $28.6 \%$ expected revenues from 200 thousand to one million and $26.7 \%$ were preparing for revenues higher than one million EUR. As many as $55.4 \%$ of the subjects in a given cluster have two to four employees, while another $41.1 \%$ have ten to 24 .

All tour operators from the cluster are operated as a trading company. Six out of ten successful solitaires have their headquarters in western Slovakia, $12.5 \%$ in the Central and an exact quarter $(25.0 \%)$ in Eastern Slovakia. As many as $71.4 \%$ of tour operators are based in the regional city. More than half $(51.7 \%)$ are based in a city with a population of more than 100,000 , about a third (35.7\%) are located in a city with 20,000 to 99,999 inhabitants. The majority (87.5\%) have only one physical establishment. Up to $85.7 \%$ of successful solitaires are also outbound tour operators. Tour operators with a specialized product have a slight predominance $(51.8 \%)$. The vast majority $(78.6 \%)$ have several destination countries in their product portfolio.

T a ble 3

Profiles of Tour Operator Clusters

\begin{tabular}{|c|c|c|c|c|}
\hline Criteria & Big players & $\begin{array}{c}\text { Successful } \\
\text { solitaires }\end{array}$ & $\begin{array}{c}\text { Small } \\
\text { partners }\end{array}$ & $\begin{array}{c}\text { Independent } \\
\text { drawers }\end{array}$ \\
\hline $\begin{array}{l}\text { Membership in Slovak Association of Tour } \\
\text { Operators and Travel Agents (in \%) } \\
\text { Membership in IATA (in \%) }\end{array}$ & $\begin{array}{r}100.0 \\
50.0\end{array}$ & $\begin{array}{l}0.0 \\
3.7\end{array}$ & $\begin{array}{r}100.0 \\
0.0\end{array}$ & $\begin{array}{l}0.0 \\
1.1\end{array}$ \\
\hline \multicolumn{5}{|c|}{ Number of employees } \\
\hline $\begin{array}{l}0-1(\text { in } \%) \\
2 \text { (in } \%) \\
3-4(\text { in } \%) \\
5-9(\text { in } \%) \\
10-24(\text { in } \%) \\
25-49(\text { in } \%) \\
50-99(\text { in } \%) \\
100-149(\text { in } \%) \\
250-499(\text { in } \%) \\
\text { Total }\end{array}$ & $\begin{array}{r}0.0 \\
3.6 \\
7.1 \\
10.7 \\
46.4 \\
17.9 \\
7.1 \\
7.1 \\
0.0 \\
28 \\
\end{array}$ & $\begin{array}{r}0.0 \\
30.4 \\
25.0 \\
25.0 \\
16.1 \\
0.0 \\
1.8 \\
0.0 \\
1.8 \\
56 \\
\end{array}$ & $\begin{array}{r}50.0 \\
11.7 \\
18.3 \\
20.0 \\
0.0 \\
0.0 \\
0.0 \\
0.0 \\
0.0 \\
60 \\
\end{array}$ & $\begin{array}{c}100.0 \\
0.0 \\
0.0 \\
0.0 \\
0.0 \\
0.0 \\
0.0 \\
0.0 \\
0.0 \\
88 \\
\end{array}$ \\
\hline \multicolumn{5}{|c|}{ Planned revenues for sales of packages of travel services and linked travel arrangements (in EUR) } \\
\hline $\begin{array}{l}\text { Mean } \\
\text { Std. Deviation }\end{array}$ & $\begin{array}{r}7,691,000 \\
11,521,911\end{array}$ & $\begin{array}{l}1,475,631 \\
3,253,646\end{array}$ & $\begin{array}{l}415,854 \\
672,697\end{array}$ & $\begin{array}{l}243,722 \\
894,156\end{array}$ \\
\hline
\end{tabular}

Source: Authors calculation.

The members of the Small partners' cluster belong without exception to the Slovak Association of Tour operators and Travel Agents, but none of them focuses on the sale of tickets as an IATA member. Half of the cluster has a maximum of 
one employee, the other half has two to nine employees. Revenues from the sale of the cluster's own packages of travel services are not high. As many as $48.3 \%$ of Small partners planned revenues of up to 200,000 euros in 2019, 31.7\% estimated to have a revenue range of 200,000 euros to 500 thousand and only $20 \%$ have revenues from 1 to 5 million euros.

While $11.7 \%$ of tour operators are trade license companies, the rest is operated as a limited liability company or joint stock company. The majority $(65.0 \%)$ of Small Partners are located in Western Slovakia, a fifth in Central and $15.0 \%$ in Eastern Slovakia. Almost seven out of ten (68.3\%) entities have their registered office located in the regional city. More than half $(56.7 \%)$ of tour operators are based in a city with less than 100,000 inhabitants. As many as $88.3 \%$ of entities are outbound tour operators. $68.3 \%$ are devoted to general offers i.e., not to specialized travel agents. Nine out of ten $(91.7 \%)$ tour operators have at most only one establishment, the remaining $8.3 \%$ have two or three branches.

The most numerous group is Independent drawers. They have the lowest revenues from the sale of their own packages. We therefore assume that they are largely engaged in the sale of packages of other tour operators i.e., they perform the role of tour operators. As many as $78.4 \%$ expected revenues for their own packages in the amount of up to 200 thousand euros in 2019, $15.9 \%$ expected revenues of 200 to 500 thousand and only $5.7 \%$ estimated them in the interval of 500 thousand to one million euros. No entity is a member of a trade union and only one tour operator is a member of IATA. All Independent drawers have only one employee.

$33.0 \%$ do business as individuals, which is the largest share of all clusters. All entities have only one or no physical location. The location of tour operators is as follows $-59.1 \%$ are located in Western Slovakia, $27.3 \%$ in Central Slovakia and $13.6 \%$ in Eastern Slovakia. More than half of tour operators (51.1\%) are located in the regional city. Only $36.4 \%$ do business in a Bratislava or Košice. Independent drawers are mainly located in smaller cities. Even in the case of this cluster, outbound tourism dominates $(87.5 \%)$, but the majority $(54.5 \%)$ of tour operators have a specialized product.

\section{Discussion}

Tour operators are important intermediary in the tourism market. They have stabilized their position despite technological progress and changes in demand, which had been reflected in massive growth in sales of individual services and complex tourism products via the Internet. However, in the short and long term, they are currently facing a more turbulent era, caused by measures related to the 
global COVID-19 pandemic. How the tour operators handle this situation, how many of them will end their existence or modify their product offer is largely unknown today.

Although only two large tour operators went bankrupt in 2020 in Slovakia, the number of enterprises that took out insolvency insurance for the following year, which allows them to sell their own travel packages, has fallen dramatically. As tour operators have to repay advances on non-executed package tours by the end of summer 2021, and due to pandemic constraints, they do not have the cash. It can be assumed that despite the loan scheme, the number of players in the market will decrease.

In this paper, we performed an analysis of the industry on the example of Slovakia. With the purpose of comparing data with a similar market (Czech Republic), we shortly analyzed the financial indicators of tour operators used by Hedija (2017) and Hedija and Kuncová (2018). We state that Slovak tour operators are financially slightly healthier than companies in the Czech Republic in the comparable period. However, in both cases, it can be expected that the excessive number of tour operators will be reduced in the coming years.

Unlike previously published articles (Pachingerová, 2001; Hedija, 2017; 2019; Derco, 2018; Hedija and Kuncová, 2018 and others), we did not draw information only from financial statistics. It has been confirmed that the statistical database provides only a distorted picture of tour operators. Therefore, we consider the research methodology to be appropriately chosen.

The results showed that with the growing number of physical locations and employees, the planned revenues of tour operators are grow. Our findings do not correspond to the results of the analysis of Spanish and Portuguese tour operators (Assaf, Barros and Dieke, 2011), where group membership affect tour operator efficiency. Here it is appropriate, so that the Slovak Association of Tour Operators and Travel Agents has thought about how to help its members to achieve better results and at the same time get an argument for the inclination of non-member tour operators.

We consider the identifying four groups of tour operators with the use of the cluster analysis to be unique. Its outputs suggest a significant difference between more successful entities with higher average revenues (Big players, Successful solitaires) and enterprises for which organizing packages of travel services is more of a casual activity (Small partners, Independent drawers). They are mainly engaged in commission sales, which is most affected by the COVID-19 crisis and will contribute to reducing the number of entities in the industry, also with regard to their financial health (Hedija, 2017; Hedija and Kuncová, 2018). Less successful tour operators possibly will disappear, transform into travel agencies, or take risks and try to gain clients with a completely new, innovative product. 
As there is no similar analysis of the tour operator industry, we call for greater inclusion of this topic in scientific literature and for the opening of a discussion on the future of tour operators and their role in the $21^{\text {st }}$ century.

Though the focus here was on cluster analysis, we feel that it is important to mention some concerns in the tourist industry in general. COVID-19 has shown a myopic focus on one type of tourism, most notably (for Slovakia) seaside destinations, come with risk and does little to help expand domestic tourist destinations. Political instability is another issue with seaside destinations. A bigger concern that is playing out especially in Europe is over-tourism and a rising opposition to the throngs of people in premier destinations (for Slovakia, this would be the High Tatras, which is quickly reaching the limits of capacity). The solution to this problem would be an expansion of a countries offering to places that are less well-known, but nevertheless, offers more sustainable tourism that integrate local populations and both natural and human environments of host countries (Theng, Qiong and Tatar, 2015). Therefore, we see the need for a future direction of tour operators that can highlight authenticity of a country as mentioned in several studies (e.g., Domínguez-Quintero, González-Rodríguez and Paddison, 2020; Yu, Li and Xiao, 2020). This will help expand offerings beyond "bucket list" destinations located in tourist ghettos and by doing so, help mitigate the ebbs and flows of destination choices offered by tourist operators.

\section{Conclusions}

The mild concentration of 4 big players is characteristic for tour operators in Slovakia generating more than a third of all revenues from packages of travel services in Slovakia. The amount of revenues in the industry while dependent on the local market potential (size of the municipality where the tour operator's headquarters is located) and the size of the enterprise (number of employees and number of branches).

Most entities have their location in the West of the country, where the average standard of living of potential clients is higher. A typical tour operator in the Slovak market has only one employee and one physical contact point. It is not a member of the Slovak Association of Tour operators and Travel Agents, nor a member of IATA and its revenues for its own (especially outbound) products are less than 200 thousand euros. It is characteristic for tour operators in Slovakia that in addition to organizing packages of travel services, they also sell packages arranged by other (larger) tour operators. In jest, we can call them, not the tour operators, but "tour sellators", as they are half tour operators and half travel agencies. At the beginning of the investigation, we supposed that the market 
would be more homogeneous. However, the heterogeneity of the industry is also evidenced by the result of the cluster analysis, according to which we can differentiate four groups of tour operators in Slovakia, which are relatively consistent in terms of the number of employees, planned revenues and membership in associations. We consider enterprises for which organizing packages of travel services is only an ancillary activity (Small partners, Independent drawers) to be more at risk due to the corona crisis, and we expect them to fall by a third, given the financial health of businesses in the industry.

The initial results of the analysis of the industry are a prerequisite for the much deeper examination of tour operators in the Slovak market with an emphasis on the introduction of alternative products in accordance with the recommendations of the UNWTO (2019). In our opinion, those tour operators who manage to survive the consequences of the COVID-19 will eventually move away from mass $3 \mathrm{~S}$ holidays product and bring new wind to the industry. It will be interesting to see how innovative and bold some companies will be, and whether they will incorporate relatively unthinkable sharing services from digital platforms into their business.

The paper presents a basic foundation for the study and understanding of the specifics of tour operator industry in Slovakia. It should be valuable for academics as a tool to compare other researched markets, for tourism students, but also for economic practice.

\section{References}

ASSAF, A. G. - BARROS, C. P. - DIEKE, P. U. C. (2011): Portuguese Tour Operators: A Fight for Survival. Journal of Air Transport Management, 17, No. 3, pp. 155 - 157. DOI: 10.1016/j.jairtraman.2010.12.002.

BREZINA, I. - ORŠULOVÁ, A. - PEKÁR, J. (2009): Analýza absolútnej koncentrácie vybraného odvetvia pomocou Herfindahlovho-Hirschmanovho indexu. Ekonomický časopis/Journal of Economics, 57, No. 1, pp. $77-94$.

BUHALIS, D. - LAWS, E. (2001): Tourism Distribution Channels: Practices, Issues and Transformations. London: Continuum. ISBN 0-82645-470-4.

DERCO, J. (2018): Financial Position of the Tour Operators in the Slovak Republic. Turizam: međunarodni znanstveno-stručni časopis, 66, No. 4, pp. $476-479$.

DHIMAN, M. CH. - KUMAR, R. B. (2019): Building Foundations for Understanding the International Travel Agency and Tour Operation. In: DHIMAN, M. Ch. and CHAUCHAN, V. (eds): Handbook of Research on International Travel Agency and Tour Operation Management. Hershey: IGI Global, pp. $1-13$.

DOMÍNGUEZ-QUINTERO, A. M. - GONZÁLEZ-RODRÍGUEZ, M. R. - PADDISON, B. (2020): The Mediating Role of Experience Quality on Authenticity and Satisfaction in the Context of Cultural-Heritage Tourism. Current Issues in Tourism, 23, No. 2, pp. $248-260$. DOI: $10.1080 / 13683500.2018 .1502261$.

ERCEG, A. - SEKULOSKA, J. D. - KELIĆ, I. (2020): Blockchain in the Tourism Industry A Review of the Situation in Croatia and Macedonia. Informatics, 7, No. 1, p. 5. DOI: 10.3390/informatics7010005. 
GAJDOŠÍK, T. - GAJDOŠÍKOVÁ, Z. - MARČEKOVÁ, R. (2017): Informačné technológie v cestovnom ruchu. Bratislava: Wolters Kluwer. ISBN 978-80-8168-587-3.

GÚČIK, M. et al. (2006): Cestovný ruch, hotelierstvo a pohostinstvo. Výkladový slovník. Bratislava: Slovenské pedagogické nakladatel'stvo. ISBN 80-10-00360-3.

HEDIJA, V. - KUNCOVÁ, M. (2018): Hodnocení finačního zdraví českých cestovních kanceláří. Scientific Papers of the University of Pardubice - Series D, 42, No. 1, pp. 53 - 66.

HEDIJA, V. (2017): Financial Helth of Travel Agencies and Tour Operators in the Czech Republic: Evidence from Bankrupcy Models. In: 4th International Multidisciplinary Scientific Conference on Social Sciences and Arts SGEM 2017. Sofia: STEF92 Technology, pp. 325 - 330. DOI: $10.5593 /$ sgemsocial2017/14/S04.043.

HEDIJA, V. (2019): Are Bankruptcy Models a Good Predictor of Firm Financial Distress of Travel Agents in the Czech Republic? Journal of International Scientific Publications - Economy and Business, 13, No. 1, pp. 87 - 93.

HOLLAND, J. - LESLIE, D. (2018): Tour Operators and Operations Development, Management \& Responsibility. Oxford: CABI. ISBN 978-1780648231.

HOLLOWAY, J. Ch. (2009): The Business of Tourism, Eighth Edition. London: Prentice Hall. ISBN 978-0273717102.

JURČOVÁ, M. (2020): Prvé slovenské aj európske skúsenosti s novou právnou úpravou zájazdov a spojených cestovných služieb. Studia Turistica, 11, No. 1, pp. $16-25$.

LINDEROVÁ, I. - JANEČEK, J. (2017): Accessible Tourism for All - Current State in the Czech Business and On-business Environment. E+M Ekonomie a Management, 20, No. 4, pp. 168 - 186.

MARIN-PANTELESCU, A. - MANIU, L.-C. (2014): The Analysis of the Romanian Tour Operator Agencies Sector. Knowledge Horizons - Economics, 6, No. 4, pp. $171-174$. DOI: $10.15240 /$ tul/001/2017-4-012.

ONUFEROVÁ, E. - ČABINOVÁ, V. (2018): Enterprise Performance Analysis of the Selected Service Sector by Applying Modern Methods with an Emphasis on the Creation and Application of the Modified Creditworthy Model. Journal of Tourism and Services, 9, No. 17, pp. $1-26$. DOI: $10.29036 /$ jots.v9i17.74.

ORIEŠKA, J. (2011): Služby v cestovnom ruchu I. čast'. Banská Bystrica: DALI-BB. ISBN 978-80-89090-93-8.

PACHINGEROVÁ, M. (2001): Small and Medium Enterprises in Slovakia Focusing on Tourism. Ekonomický časopis/Journal of Economics, 49, No. 6, pp. 1173 - 1196.

POMPUROVÁ, K. (2011): Manažment prevádzky cestovnej kancelárie. Banská Bystrica: Ekonomická fakulta UMB. ISBN 978-80-557-0314-5.

ŠOLCOVÁ, L. - PETRIKOVIČ, J. (2019): Spatial Aspect and Behavior of Tour Operators in Slovakia. In: 22nd International Colloquium on Regional Sciences. [Conference Proceedings.] Brno: Masaryk University Press, pp. 587 - 606. DOI: 10.5817/CZ.MUNI.P210-9268-2019-76.

THENG, S. - QIONG, X. - TATAR, C. (2015): Mass Tourism vs. Alternative Tourism? Challenges and New Positionings. Études Caribéennes, $31-32$, pp. 1 - 8 .

UNWTO (2019): Recommendations on Sustainable Development of Indigenous Tourism. Madrid: World Tourism Organization. ISBN 978-92-844-2128-2.

YU, J. - LI, H. - XIAO, H. (2020): Are Authentic Tourists Happier? Examining Structural Relationships amongst Perceived Cultural Distance, Existential Authenticity, and Wellbeing. International Journal of Tourism Research, 22, No. 1, pp. 144 - 154. DOI: 10.1002/jtr.2324. 